|Araştırma Makalesi / Research Article |

\title{
Öğretmen Adaylarının Dijital Vatandaşlık Düzeylerinin Belirlenmesi ${ }^{1}$
}

\section{Determination Of The Digital Citizenship Levels of Prospective Teachers}

\section{Mehmet Yılmaz² ${ }^{2}$ Berrin Doğusoy ${ }^{3}$}

\section{Anahtar Kelimeler \\ Dijital Vatandaşlık \\ Tarama Modeli \\ Öğretmen Adayı}

\section{Keywords}

Digital Citizenship

Survey Study

Prospective Teacher

Başvuru Tarihi/Received

21.02.2020

Kabul Tarihi /Accepted

10.11.2020

\section{Öz}

Bu araştırmada, bir devlet üniversitesinin Eğitim Fakültesi'nde farklı bölümlerde öğrenim görmekte olan öğretmen adaylarının dijital vatandaşlık düzeylerinin farklı değişkenler açısından incelenmesi amaçlanmaktadır. Araştırma nicel araştırma yöntemlerinden tarama modelinde betimsel bir araştırmadır. Çalışmanın örneklemi belirlenen devlet üniversitesinde Eğitim Fakültesinde farklı bölümlerde öğrenim gören öğretmen adaylarından oluşmaktadır. Çalışma kapsamında alanyazında bulunan mevcut ölçekler incelenerek Som-Vural (2016) tarafından geliştirilen Dijital Vatandaşlık Ölçeğinin kullanılmasına karar verilmiştir. Ölçek 23 madde ve 5 faktörlü bir yapıdadır. Elde edilen veriler demografik değişkenler ve teknolojiye erişim ile ilgili belirlenen değişkenler açısından incelenmiştir. Veri analizi sonucunda öğretmen adaylarının dijital vatandaşlık düzeylerinin demografik değişken olarak belirlenen cinsiyet ve öğrenim görülen bölüme göre anlamlı şekilde farklılaştığı ancak sınıf, yaş aralığı ve gelir düzeyine göre anlamlı bir farklılık bulunmadığı belirlenmiştir. Öğretmen adaylarının bölüm açısından dijital vatandaşlık düzeylerinin birbirine yakın ve yüksek olması alanyazın açısından önemli bir bulgudur. Öğretmen adaylarının dijital vatandaşıı düzeyleri teknolojiye erişim olanakları değişkeni açısından incelendiğinde dijital vatandaşlık düzeylerinin bilgisayar sahibi olma, bilgisayar kullanma süresi (yıl bazında), en sık kullanılan sosyal ağda geçirilen süre, e-devlet şifresi sahibi olma ve etkin bir e-posta adresi kullanma açısından anlamlı şekilde farklılaştığı sonucuna ulaşılmıştır. Ancak öğretmen adaylarının dijital vatandaşlık düzeylerinin internet kullanma sürelerine göre anlamlı şekilde farklılaşmadığı belirlenmiştir.

\section{Abstract}

The purpose of this study is to examine prospective teachers' digital citizenship in terms of different variables. This study is a descriptive survey study which is one of the quantitative research methods. The sampling of the study consists of prospective teachers who were studying in different departments of a state university. Within the scope of the study, "Digital Citizenship Scale" which was developed by Som-Vural (2016) was determined as the data collection instrument. The scale consists of 23 items and 5 factors. The data were examined in terms of the demographic variables and variables related with access to technology. The findings showed that prospective teachers' digital citizenship levels significantly differed according to the demographic variables (gender and department). However, there was no significant difference in prospective teachers' digital citizenship levels in terms of grade level, age range and income levels. Moreover, prospective teachers' digital citizenship scores were close to each other and high level which is an important finding for the literature. According to the technology access variable, the prospective teachers' digital citizenship levels significantly differed in terms of computer ownership, computer use time, time spent in the social network, having an e-government password and using an active e-mail address. Interestingly, the digital citizenship level of the participants did not differ according to the time spent in Internet.

\footnotetext{
${ }^{1}$ Bu araştırma makalesi “Öğretmen Adaylarının Dijital Vatandaşılık Düzeylerinin Belirlenmesi: Mersin Üniversitesi Eğitim Fakültesi Örneği” isimli Yüksek Lisans Tezinden üretilmiștir.

${ }^{2}$ Sorumlu Yazar, Yüksek Lisans Öğrencisi, Mersin, TÜRKiYE; https://orcid.org/0000-0003-2020-4775

${ }^{3}$ Mersin Üniversitesi, Eğitim Fakültesi, Bilgisayar ve Öğretim Teknolojileri Eğitimi, Mersin, TÜRKiYE; https://orcid.org/0000-0002-3314-4006
}

Alıntı/Citation: Yılmaz, M., \& Doğusoy, B. (2020). Öğretmen adaylarının dijital vatandaşlık düzeylerinin belirlenmesi. Kastamonu Education Journal, 28(6), 23622375. doi: 10.24106/kefdergi.692492 


\section{Extended Abstract}

\section{Introduction}

Studies related with the new generation have brought a change in the context of applications and tools in education. Students who grow up in an environment where they interact with new technologies enjoy the environments where technology exists (Odabaşı et al., 2012). Şahin (2009) stated that the diversity between the changing student profile and the existing student profile in the education system creates an uncertainty regarding the approach to be used. However, for students who are constantly interacting with digital life, it is seen as a necessity to be informed about the conscious, effective and safe use of these digital technologies. In this context, in recent years concepts like digital citizenship, digital security and information security have entered into our daily lives. The concept of digital citizenship has been described by Ribble (2015) as "the norms of appropriate, responsible behavior with regard to technology use" (p.15). Ribble (2011) has assessed digital citizenship in 9 sub-dimensions; 1) access to digital, 2) Digital Commerce and 3) Digital Communications 4) digital literacy, 5) digital ethics, 6) Digital Law 7) digital rights and responsibilities 8) Digital Health, 9) Digital Security. The fact that people often encounter digital environments and that they remove the boundaries of communication and interaction with this environment is considered an important step towards the formation of a digital society. Teacher candidates, especially those facing a digital generation interacting with rapidly changing technologies, are also likely to face problems in terms of technological competence and awareness. The frequent use of these environments in education has brought about a need for the evaluation of program content and the current situation in order to educate students with digital citizenship awareness. Because the prospective teachers are future teacher candidates, it is important to train them as future digital citizens to use technology in education and training processes. At this point, the teachers who should be an example in terms of digital citizenship play an important role in this process. Therefore, considering the importance of teacher education, it is important to describe the level of digital citizenship of the prospective teachers. Within the scope of this research, it is aimed to reveal the current situation of the prospective teachers who are growing up in an environment surrounded by mobile technologies and who will serve as teachers in different fields in the future.

\section{Method}

This study is a descriptive survey research aims to reveal the digital citizenship levels of teacher candidates studying in different departments in a state university. Survey research is one of the quantitative research methods aiming to collect data to determine the characteristics of a group (Büyüköztürk, Çakmak, Akgün, Karadeniz and Demirel, 2017). Karasar (1984) explained survey study as "aiming to describe a situation that exist in the past or present as it exist" (p.80). Data were collected through digital citizenship scale which was developed by Som-Vural (2016) consisting of 23 items and 5 factors. The sub factors are respectively online procedures, correct usage, access, health and social responsibility. 1151 prospective teachers studying in different departments during 2018-2019 academic year fall semester were participated to the study. The scale's reliability and validity issues were ensured by Som-Vural (2016) as the Cron-Bach Alpha ( $\alpha$ ) coefficient for the entire scale is $\alpha=, 865$, the coefficients for the lower dimensions of the scale vary between 618 and 847 . In this study, reliability analyses were performed for the entire digital citizenship scale. The Cronbach Alpha fold-number $\alpha=, 857$ was calculated with respect to the reliability of the entire scale. The reliability analysis of the lower dimensions of the scale revealed that the Cron-Bach Alpha coefficients are between $\alpha=, 614$ and $\alpha=$ ,852. The internal consistency coefficient for the entire measurement instrument was calculated as $\alpha=, 857$.

\section{Result and Discussion}

The results of this study revealed that there were significant differences in prospective teachers' digital citizenship scores in terms of gender and department. However, there was no significant difference between grade level, age range and income levels. The findings suggested that there was a statistically significant difference between the digital citizenship levels and gender of the teacher candidates and that significant difference is in favor of female prospective teachers. In a similar vein, Som-Vural (2016) concluded that the digital citizenship levels of university students differed significantly in favor of women. On the other hand, Kocadağ (2012) and Özerbaş and Kuralbayeva (2018) determined that gender-related significant differences were in favor of men. Kocadağ (2012) stated the abstainer behavior pattern of women in digital media. The findings of the study might support the idea abstainer behavior patterns of women in digital media may have changed in recent years. However, the causes of this change need to be investigated in future studies. In addition the digital citizenship levels of the prospective teachers were examined according to their technology access possibilities. It was concluded that citizenship levels differed significantly in terms of computer ownership, computer usage time (by year), time spent on the most common social network, e-government password ownership and using an active e-mail address. The findings of the study showed that majority of the teacher candidates owned a computer, and had experience of 7-10 years. In the literature, there were studies that match with the findings of this study examining the levels of computer ownership and digital citizenship (Aslan, 2016; Kocadağ, 2012).

Although in the literature the daily internet usage time and digital citizenship considered as related (Al-Zahrani, 2015; Aslan, 2016; Choi, Cristol and Gimbert, 2018; Berardy, 2015; Som-Vural, 2016; Kabatas 2019), surprisingly in this study prospective teachers' digital citizenship scores did not differ according to their daily internet usage time. In order to determine the reasons laying beneath for this inconsistency with the literature, qualitative research studies can be designed in future. In conclusion, it 
was determined that the prospective teachers participated in the study had high levels of digital citizenship and female participants' digital citizenship scores were higher than males. According to the departments, prospective teachers in the department of Computer Education and Instructional Technology had the highest digital citizenship score while prospective teachers in the department of Primary education had the lowest score. However, it was found that digital citizenship scores of all departments were very close to each other. This may interpreted as the new generation prospective teachers were more conscious group in terms of digital citizenship. It was also concluded that the majority of prospective teachers have an active email address, use social networks and e-government applications regularly. In addition, it was concluded that the level of digital citizenship did not differ according to income level, class and age, but differed in terms of internet usage behaviors.

\section{Giriş}

Internet teknolojilerindeki son gelişmeler bireylerin yaşam biçimlerini de belirgin bir şekilde değiştirmiştir. Teknolojik gelişmelerin etkisi sağlıktan, endüstriye, eğitimden iletişime birçok alanda hissedilmektedir. Alanyazında bu teknolojik gelişmeler bağlamında yeni terimler ve tanımlamalar yapılmıştır. Bu bağlamda dijital kuşak, millenials (Oblinger, Oblinger ve Lippincott, 2005), dijital yerli ve dijital göçmen (Prensky, 2001), net kuşağı (Tapscott, 1998) vb. gibi terimler hayatımıza girmiştir. Bu terimler ile ilgili olarak dijital yerli ve dijital göçmen kavramlarını ortaya atan Prensky (2001), gençlerin bilgi ve iletişim teknolojilerini kullanımları açısından kendilerinden önceki kuşaklardan ve öğretmenlerinden farklılaştığını belirtmiştir. Ancak son yıllarda bu bakış açısının özellikle genç kuşak ve bu kuşak ile ilişkilendirilen özelliklerine yönelik eleştiriler de bulunmaktadır. Bennett, Maton ve Kervin (2008), araştırmalarında dijital yerli bir grup olarak genellenen genç kuşak ile ilgili yapılan çıkarımların ampirik desteklerinin azlığını vurgulamıştır. Bunun yanısıra genç kuşak ile ilgili yapılan genellemelerde gençlerin büyük bir bölümünün varsayılan teknolojik erişim ve becerilere sahip olmayabileceği ve bu grubun göz ardı edilme tehlikesinin varlığı da vurgulanmıştır (Bennett, Maton ve Kervin, 2008). Benzer şekilde Akçayır, Dündar ve Akçayır (2016), üniversite öğrencilerinin teknolojik yeterliliklerini belirlemeye yönelik çalışmalarında, öğrencilerin etkin şekilde bilgisayar ve internet kullandıklarını ve dijital yerliler için kullanılan yıl ve yaş sınırlamasından öte artık öğrencilerin sınıfları, kültür seviyeleri ve teknoloji ile ilgili deneyimlerine göre nitelendirilebileceklerini belirtmişlerdir.

Yeni nesil ile ilgili çalışmalar ve teknolojik gelişmeler eğitim öğretim süreçlerinde uygulama ve araç bağlamında da bir değişimi beraberinde getirmiştir. Yeni teknolojiler ile etkileşimde bir ortam içinde büyüyen öğrenciler teknolojinin olduğu ortamlardan keyif almaktadır (Odabaşı vd., 2012). Şahin (2009) ise araştırmasında değişen öğrenci profili ve eğitim sisteminde mevcut öğrenci profili ile ilgili yaşanan olanak uyuşmazlığının bu öğrencilere yaklaşım ile ilgili bir belirsizlik oluşturduğunu belirtmiştir. Ancak son yıllarda yeni nesil öğrencilerin dijital yaşam ile sürekli etkileşim içinde olmasından dolayı bu teknolojileri bilinçli, etkili ve güvenli kullanmaya yönelik bilgi sahibi olmaları da bir gereklilik olarak görülmektedir. Bu bağlamda son yıllarda dijital vatandaşlık, dijital güvenlik ve bilgi güvenliği gibi kavramlar günlük yaşantımıza girmiştir. Alanyazında dijital vatandaşlık kavramı Ribble (2015) tarafından "teknoloji kullanımı sırasında uygun, sorumlu davranış normları" olarak tanımlanmıştır (s.15). Oyedemi (2012), dijital vatandaşı ık bileşenlerini; "1) vatandaşlık hakları ve insan hakları, 2) iletişim teknolojilerine erişim, 3) iletişim teknolojilerini uygulayabilme becerisi, 4) bu teknolojilerin düzenli kullanımı ve 5) bu bileşenlerin uygulanmasını mümkün kılan politika" (s.201201) olmak üzere 5 boyuta ayırmıştır. Ribble (2011) ise dijital vatandaşlığı 9 alt boyutta 1) dijital erişim, 2) dijital ticaret, 3) dijital iletişim, 4) dijital okuryazarlık, 5) dijital etik, 6) dijital hukuk, 7) dijital haklar ve sorumluluklar, 8) dijital sağlık, 9) dijital güvenlik olarak değerlendirmiştir.

"21. Yüzyılda Vatandaşlığı yeniden düşünmek" başlıklı raporda dijital vatandaşlık tanımlanan öğeler arasında bulunmaktadır (P21, 2013, akt. Fırat, 2016). Fırat'a (2016) göre “21. Yüzyılda ihtiyaç duyulan insan profili sürekli eğitim ve yaşam boyu öğrenme temelinde kendi kendine öğrenme, teknoloji ve bilgi okuryazarlığı, yabancı dil, dijital vatandaşlık, değişen koşullara uyum sağlama ve sürekli güncellenen bilgiyi takip etme yeterlikleri etrafında şekillenmektedir"(s.143). Bunun yanısıra Uluslararası Eğitim Teknolojileri Derneği (International Society for Technology in Education, ISTE) yayınladığı Ulusal Eğitim Teknolojileri Standartlarında (National Educational Technology Standards for Students, NETS) eğitim teknolojilerinin etkili kullanımı için farklı gruplara yönelik standartlar geliştirmiştir. Dijital vatandaşılı da bu standartlar içinde sahip olunması gereken yeterlilikler arasında tanımlanmıştır. ISTE (2014) Öğrenciler için geliştirilen Ulusal Eğitim Teknolojileri Standartları (NETS-S) içinde dijitalleşen dünyada öğrencilerin verimli bir öğrenme için sahip olması gereken bilgi ve beceriler içinde de dijital vatandaşlık belirtilmiştir. Benzer şekilde öğretmenler için geliştirilen Ulusal Eğitim Teknolojileri Standartlarında (NETS-T) dijital vatandaşlıkta model olma öğretmenlerin sahip olması gerektiği belirtilen 5 yeterlilikten biri olarak belirtilmiştir (ISTE, 2014). Benzer şekilde Fırat (2016) 21. yüzyılın gereksinim duyulan insan profilinde dijital vatandaşlığı önemli bir kriter olarak belirtmiştir. Gülseçen, Özdemir, Çelik, Uğraş ve Özcan (2014), dijital vatandaşlığın, çocukların teknoloji kullanan bir topluma hazırlanmasına yardımcı olan bir kavram olduğunu ifade etmiştir.

\section{Dijital vatandaşlık ile ilgili yapıımış çalışmalar}

Alanyazın taraması araştırmalarda farklı örneklem grupları ile çalışıldığını göstermektedir. Bu çalışmalarda sıklıkla araştırılan örneklem grupları içinde ilköğretim öğrencileri (Elçi ve Sarı, 2016; Karaduman, 2011; Öztürk, 2015), üniversite öğrencileri (Kara, 2018; Kuş, Güneş, Başarmak ve Yakar, 2017; Som-Vural, 2016) ve genç yetişkinler (Choi, Glassman ve Cristol, 2017), öğretmen adayları (Aslan, 2016; Bakır, 2016; Görmez, 2016; Kaya ve Kaya, 2014; Kocadağ, 2012; Özerbas ve Kuralbayeva, 2018; Sakallı, 2015) 
ve öğretmenler (Tatlı, 2018) bulunmaktadır. Alanyazında ağırlıklı olarak öğrenciler ve öğretmen adaylarına odaklanıldığı görülmektedir. Öğretmen adayları ile yapılan çalışmalarda; dijital vatandaşlık düzeyi (Kocadağ, 2012; Kuş, Güneş, Başarmak ve Yakar, 2017; Özerbaş ve Kuralbayeva, 2018) ve dijital vatandaşlık algısı (Bakır, 2016; Kaya ve Kaya, 2014), siber zorbalık eğilimi ile dijital vatandaşlık ilişkisi (Sakallı, 2015), yaşam boyu öğrenme ile dijital vatandaşlık ilişkisi (Kabataş, 2009), dijital vatandaşlık düzeyinin internet ve bilgisayar kullanmaya yönelik beceriler ile bilgi okuryazarlığı açısından değerlendirilmesi (Tatlı, 2018) konularına odaklanılmıştır.

Eğitim yoluyla dijital vatandaşlığın geliştirilmesine yönelik artan bir ilgi bulunduğunu vurgulayan Jones ve Mitchell (2016) çevrimiçi saygılı davranış ve çevrimiçi sivil katılım boyutlarına yönelik bir dijital vatandaşık ölçeği geliştirmişlerdir. Araştırmada yaş azaldıkça çevrimiçi saygılı davranışın düştüğü, saygılı çevrimiçi davranış ve sivil katılım boyutunda kızların erkeklerden daha yüksek puanlar aldığı sonucuna ulaşılmıştır. Gleason ve von Gillern (2018) çalışmalarında öğrencilerin sosyal medya kullanımının formal ve informal öğrenme ortamlarında dijital vatandaşlık gelişimini sağlamak için nasıl kullanılabileceğini belirmeye çalışmışlardır. Öğrencilerin ekran karşısında geçirdikleri süreler göz önüne alındığında bilgiyi sorumlu bir şekilde bulma, değerlendirme ve paylaşma ile ilgili becerilerinin geliştirilmesinin önemi vurgulanmıştır. Araştırmada dijital vatandaşlığın sosyal medya aracılığıyla oluşturulacak bir öğretim programına okul içi ve okul dışı dahil edilebileceği belirtilmiştir. Bu kapsamda dijital vatandaşlık ve sivil katılımın kavramsal analizi yapılarak ve dijital medya uygulamalarının ortaöğretim kurumlarında vatandaşlık eğitimini nasıl destekleyebileceği ele alınmıştır. Hollandsworth, Dowdy ve Donovan (2011) yaptıkları çalışmada dijital vatandaşlık bilinci ve eğitiminin eksikliğinin sorunlu hatta tehlikeli kabul edilebilecek öğrenci davranışlarına yol açabileceğini belirtmiştir. Üniversite öğrencileri ile çalışan Netwong (2016) dijital vatandaşıı ile akademik başarı arasında yüksek düzeyde bir ilişki olduğunu belirlemiştir. Berardi (2015) beş devlet okulundan 64 ilköğretim öğretmeni ile çalıştığı araştırmada dijital vatandaşlık ile ilgili en yüksek özyeterliliğe sahip öğretmen grubunun ilköğretim öğretmenleri olduğunu belirlemiştir. Choi, Cristol ve Gimbert (2018) araştırmalarında öğretmenlerin dijital vatandaşlık düzeyleri ve bunu etkileyen faktörleri incelemişlerdir. Araştırmada internet özyeterliliği ile dijital vatandaşlık arasında güçlü bir ilişki bulunmasının yanısıra iş tecrübesi, sosyal ağların öğretim amaçlı kullanımı ve internet öz yeterliliği değişkenlerinin öğretmenlerin dijital vatandaşlık algılarını önemli şekilde etkilediği belirlenmiştir. Pescetta (2011) dijital vatandaşlığın gerekliliği ve öğretmenlerin sahip olması gereken beceriler ile ilgili çalışmasında teknoloji sayesinde toplumun iletişim yolları değişmeye devam ettiği sürece öğretmenlerin dijital okuryazarlık ve yeterlilikler açısından öğrencilerini hazırlamaları gerektiği sonucuna ulaşmışlardır.

Alanyazındaki eğilim incelendiğinde günümüzde insanların dijital ortamlar ile sıklıkla karşılaşması ve bu ortamların iletişim ve etkileşim ile ilgili sınırları kaldırması dijital toplum oluşması yolunda önemli bir adım olarak kabul edilebilir. Özellikle hızlı değişen teknolojiler ile etkileşimde olan bir dijital kuşak ile karşı karşıya olan öğretmen adaylarının teknolojik yeterlilik ve farkındalık anlamında da sorunlar ile karşılaşması olasıdır. Bu ortamların eğitimde sıklıkla kullanılması da öğrencilerin dijital vatandaşlık bilinci ile yetiştirilmesi için mevcut durumun ortaya konulması ve program içeriklerinin değerlendirilmesine yönelik bir ihtiyacın oluşmasını beraberinde getirmiştir. Öğretmen adaylarının geleceğin öğretmenleri olmalarından dolayı eğitim-öğretim süreçlerinde teknoloji kullanımı ve dijital vatandaşıı açısından mevcut durumlarını ortaya koymak geleceğin dijital vatandaşlarını yetiştirmek adına önem taşımaktadır. Bunun yanısıra öğrencilerin iyi bir dijital vatandaş olarak yetiştirilmesi dijital vatandaşlık ile ilgili tüm eğitim yaşantılarında iyi örnekler ile karşılaşmaları ile mümkün olabilir. Bu noktada dijital vatandaşlık açısından örnek olması gereken öğretmenler önemli bir rol üstlenmektedir. Bundan dolayı öğretmen eğitiminin önemi göz önünde bulundurulduğunda, eğitim fakültesi öğrencilerinin dijital vatandaşlık düzeylerinin betimlenmesi oldukça önemlidir.

$\mathrm{Bu}$ araştırma ile öğretmen adaylarının dijital vatandaşlık düzeylerinin belirlenmesi ve buna yönelik önerilerde bulunulması hedeflenmektedir. Öğretmen adayları ve öğretmen eğitimi zincirleme bir etkiye sahip olması anlamında kritik bir önem taşımaktadır. Dolayısıyla araştırma, sadece öğretmen adaylarının eğitimine değil, söz konusu öğretmen adaylarının öğrencilerinin eğitimine de fayda sağlayacaktır. Bu bağlamda araştırmanın geleceğin öğretmen adaylarına yönelik durumu ortaya koymasının yanı sıra elde edilecek bulgular ışığında verilecek önerilerle öğrencilerin dijital vatandaşlık bilinci kazanmasına yönelik potansiyel etkisi ile alanyazına katkıda bulunacağı düşünülmektedir. Bu bağlamda araştırma kapsamında farklı bölümlerde öğrenim gören öğretmen adaylarının dijital vatandaşıı düzeylerinin farklı değişkenler açısından incelenmesi amaçlanmaktadır. Bu amaç doğrultusunda aşağıdaki araştırma sorularına cevap aranmıştır:

1. Öğretmen adaylarının dijital vatandaşlık düzeylerine ilişkin değerleri demografik değişkenler (cinsiyet, bölüm, sınıf, yaş aralığı, gelir düzeyi) açısından farklılık göstermekte midir?

2. Öğretmen adaylarının dijital vatandaşlık düzeylerine ilişkin değerleri teknolojiye erişim olanaklarına (bilgisayar sahibi olma, bilgisayar kullanma süresi, internet kullanma süresi, e-posta hesabı kullanma, e-devlet şifresine sahip olma, en sık kullandıkları sosyal ağda geçirdikleri süre) göre farklılık göstermekte midir?

- Öğretmen adaylarının internete bağlandıkları yer ve araçlar ile kullandıkları sosyal ağlar ve e-devlet uygulamaları nelerdir?

\section{YÖNTEM}

Bu bölümde araştırmanın yöntemi, örneklem, veri toplama araçları ve veri analizi süreci ile ilgili açıklamalara yer verilmiştir. 
Bu araştırma, bir devlet üniversitesinin Eğitim Fakültesinde farklı bölümlerde öğrenim görmekte olan öğretmen adaylarının dijital vatandaşlık düzeylerini ortaya koymayı amaçlayan betimsel bir araştırmadır. Araştırmada nicel araştırma yöntemlerinden tarama modeli kullanılmıştır. Tarama araştırması; bir grubun belirli özelliklerini belirlemek için veri toplanmasını amaçlayan çalışmalardır (Büyüköztürk, Çakmak, Akgün, Karadeniz ve Demirel, 2017). Karasar (1984), tarama modelini "geçmişte ya da halen varolan bir durumu varolduğu şekliyle betimlemeyi amaçlayan araştırma yaklaşımı” olarak tanımlamıştır (s. 80). Tarama araştırmalarında, genellikle geniş bir kitleden veri toplanır. Araştırmacılar tarama araştırmalarında, görüşlerin ve özelliklerin neden kaynaklandığından çok örneklemdeki bireyler açısından nasıl dağıldığıyla ilgilenmektedir (Fraenkel, Wallen ve Hyun, 2012). Bu çalışmanın betimsel tarama modelinde bir araştırma olmasından dolayı öğretmen adaylarının dijital vatandaşlık düzeylerini etkileyen nedenlere odaklanılmamıştır.

\section{Örneklem}

Çalışmanın örneklemi 2018-2019 eğitim-öğretim yılı güz yarıyılında, bir devlet üniversitesinde Eğitim Fakültesinde farklı bölümlerde öğrenim gören ve çalışmaya gönüllü olarak katılan öğretmen adaylarından oluşmaktadır. Örneklem grubu belirlenirken seçkisiz olmayan örneklem yöntemlerinden uygun örnekleme yöntemi kullanılmıştır. Bu örneklem belirleme yöntemi, araştırmacı açısından kolay ulaşılabilir olan bir örneklemden veri toplanmasını ifade eder (Büyüköztürk, Çakmak, Akgün, Karadeniz ve Demirel, 2017). Bu araştırma kapsamında 2018-2019 eğitim-öğretim yılı güz yarıyılında kayıtlı 1151 öğretmen adayından veri toplanmıştır. Araştırmanın çalışma grubunu oluşturan öğretmen adaylarının bölüm, sınıf ve cinsiyetlerine göre dağılımı Tablo 1'de verilmiştir.

Tablo 1. Araştırmaya katılan öğretmen adaylarının bölüm, sınıf ve cinsiyetlerine göre dağılımı

\begin{tabular}{|c|c|c|c|c|c|c|c|}
\hline BÖLÜM & 1. SINIF & 2. SINIF & 3. SINIF & 4. SINIF & $\mathrm{KIZ}$ & ERKEK & TOPLAM \\
\hline ВÖTE & 5 & 5 & 13 & 3 & 17 & 9 & 26 \\
\hline PDR & 64 & 64 & 61 & 24 & 157 & 56 & 213 \\
\hline Fen Bilgisi & 43 & 34 & 51 & 45 & 139 & 34 & 173 \\
\hline Matematik & 49 & 43 & 54 & 54 & 137 & 63 & 200 \\
\hline Türkçe & 46 & 55 & 32 & 0 & 86 & 47 & 133 \\
\hline Okul Öncesi & 47 & 46 & 56 & 21 & 133 & 37 & 170 \\
\hline Sinif & 0 & 60 & 39 & 0 & 75 & 24 & 99 \\
\hline İngilizce & 52 & 5 & 47 & 33 & 96 & 41 & 137 \\
\hline Toplam & 306 & 312 & 353 & 180 & 840 & 311 & 1151 \\
\hline
\end{tabular}

\section{Veri Toplama Aracı}

Veri toplama sürecinde Som-Vural (2016) tarafından üniversite öğrencilerine yönelik olarak geliştirilen "Dijital vatandaşlık ölçeği" ve araştırmacılar tarafından geliştirilen kişisel bilgi formu kullanılmıştır. Dijital vatandaşlık ölçeği beş faktörlü yapıda ve 23 maddeden oluşmaktadır. Ölçek içindeki maddeler katılımcıların kendilerine uygunluğunu değerlendirmeleri açısından $5^{\prime} l i$ Likert tipi dereceleme şeklinde sunulmuştur. Ölçeğin geçerlilik ve güvenirlik çalışmaları Som-Vural (2016) tarafından yapılmıştır. Ölçeğin tamamına ilişkin Cronbach Alpha ( $\alpha$ ) katsayısı $\alpha=, 865$ iken, ölçeğin alt boyutlarına ilişkin katsayıların ,618 ile ,847 arasında değiştiği görülmüştür.

Bu çalışma kapsamında elde edilen veriler ile dijital vatandaşlık ölçeğinin tamamına ve dijital vatandaşlık alt boyutlarına yönelik güvenirlik analizleri yapılmıştır. Ölçeğin tamamına ilişkin güvenirlik ile ilgili Cronbach Alpha katsayısı $\alpha=, 857$ olarak hesaplanmıştır. Ölçeğin alt boyutlarına yönelik yapılan güvenirlik analizleri sonucunda Cronbach Alpha katsayılarının $\alpha=, 614$ ile $\alpha=, 852$ arasında olduğu tespit edilmiştir. Ölçme aracının tamamına ait iç tutarlılık katsayısı $\alpha=, 857$ olarak hesaplanmıştır. Cronbach Alpha katsayıları ile ilgili alanyazında 0,6 ile 0,8 arasındaki değerlerin oldukça güvenilir, 0,80 ve 1 arasındaki değerlerin ise yüksek güvenilir olduğu belirtilmektedir (Özdamar, 2004). Bu bağlamda ölçeğin iç tutarlılık gösterdiği sonucuna ulaşılabilir.

\section{Veri Analizi}

Verilerin analizi sürecinde 1162 öğretmen adayından toplanan ölçme araçları kayıp veri olup olmadığı incelendikten sonra, 11 ölçme aracı analiz dışında bırakılmıştır. İstatistiksel analizler 1151 öğretmen adayının verileri ile gerçekleştirilmiştir. Veri girişinin tamamlanmasının ardından istatistiksel analizlerin uygulanabilmesi için gerekli ön şartları sağlamak amacıyla değişkenlerin normal dağılım gösterip göstermediğini belirlemek için çarpıklık ve basıklık değerleri incelenmiştir. Verilerin çarpıklık değerlerinin (-1.796) ile $(, 014)$ ve basıklık değerlerinin $(-, 633)$ ile $(6,485)$ arasında olduğu sonucuna ulaşılmıştır. Kline'a $(2005)$ göre normal dağılım ile ilgili olarak kabul gören değerler çarpıklık (skewness) katsayısı için 3'ten az olması, basıklık (kurtosis) katsayısı için 10'dan az olması gerekmektedir. Bu çalışmada ölçeğe ait değişkenlerin çarpıklık ve basıklık katsayılarının alanyazında belirtilen değerler aralığında olmasından dolayı verilerin normal dağılım göstermekte olduğu kabul edilerek tüm değişkenler için parametrik analizler yürütülmüştür. 


\section{BULGULAR}

Öğretmen adaylarının dijital vatandaşlık puan ortalamalarının demografik değişkenler açısından farklılık gösterip göstermediğini belirlemek amacıyla öğretmen adaylarının dijital vatandaşlık puan ortalamaları cinsiyet, bölüm, sınıf, yaş aralığı ve gelir düzeyi değişkenleri açısından incelenmiştir. Araştırma kapsamında araştıılan ikinci araştırma sorusu doğrultusunda öğretmen adaylarının dijital vatandaşlık puan ortalamalarının teknolojiye erişim olanakları açısından farklılık gösterip göstermediği incelenmiştir. Bunun için öğretmen adaylarının dijital vatandaşlık puan ortalamaları bilgisayar sahibi olma, yıl bazında bilgisayar kullanma süresi, etkin e-posta kullanma durumu, e-devlet şifresine sahip olma durumu, gün içinde internet kullanma süresi ve en sık kullandıkları sosyal ağda geçirdikleri süre değişkenleri bakımından incelenmiştir. Ayrıca ikinci araştırma sorusu kapsamında öğretmen adaylarının internete bağlandıkları yer ve araçlar, kullandıkları e-devlet uygulamaları, üye oldukları ve en sık kullandıkları sosyal ağlar ile ilgili demografik bilgiler de toplanmıştır.

\section{Öğretmen Adaylarının Dijital Vatandaşıı Ortalamalarının Cinsiyete Göre İncelenmesi}

Öğretmen adaylarının dijital vatandaşlık puanlarının cinsiyet değişkenine göre anlamlı bir farklılık gösterip göstermediğini belirlemek amacıyla bağımsız gruplar t-testi uygulanmıştır. Tablo 2'de görüldüğü üzere öğretmen adaylarının \%72,9'unun ( $\mathrm{N}=840$ ) kadın, \%27,1'i ise ( $\mathrm{N}=311)$ erkek olduğu belirlenmiştir. Yapılan analiz sonucunda kadın öğretmen adaylarının dijital vatandaşlık puan ortalamalarının ( $\bar{X}=95,2997)$ erkek öğretmen adaylarının dijital vatandaşlık puan ortalamalarından $(\bar{X}=93,0506)$ daha yüksek olduğu ve t-test analiz sonuçlarına göre kadınlar lehinde anlamlı bir farklılık olduğu sonucuna varılmıştır $(t(477,345)=2,985, p=, 03)$. Bağımsız gruplar t-testi sonucunda elde edilen sonuçlar Tablo 2'de verilmiştir.

Tablo 2. Öğretmen adaylarının dijital vatandaşlığa ilişkin ortalamalarının cinsiyet değişkenine göre karşılaştırılması

\begin{tabular}{lcccccc}
\hline Cinsiyet & $\mathrm{N}$ & $\mathrm{X}$ & $\mathrm{SS}$ & $\mathrm{t}$ & $\mathrm{df}$ & $\mathrm{p}$ \\
\hline Kadın & 840 & 95,2997 & 9,85542 & 2,985 & 477,345 &, 03 \\
Erkek & 311 & 93,0506 & 11,85657 & & & \\
\hline
\end{tabular}

p<.05

\section{Öğretmen Adaylarının Dijital Vatandaşıı Ortalamalarının Öğrenim Görülen Bölüme Göre İncelenmesi}

Öğretmen adaylarının dijital vatandaşlık puanlarının öğrenim gördükleri bölümlere göre anlamlı bir farklılık gösterip göstermediğini belirlemek amacıyla tek faktörlü varyans analizi (OneWay ANOVA) yapılmıştır. Araştırmaya katılan 8 bölüm arasında dijital vatandaşlık puan ortalaması en yüksek bölümün BÖTE bölümü $(=97,8993)$, en düşük bölümün ise Sınıf Öğretmenliği bölümü $(=92,2368)$ olduğu sonucuna ulaşılmıştır. Tablo 3'te görüldüğü üzere yapılan tek faktörlü varyans analizi sonucunda öğretmen adaylarının öğrenim gördükleri bölüm açısından dijital vatandaşlık puanlarının anlamlı şekilde farklılaştığı belirlenmiştir $(p=, 04)$.

Tablo 3. Öğretmen adaylarının dijital vatandaşlığa ilişkin ortalamalarının öğrenim görülen bölüm değişkenine göre karşılaştırılması

\begin{tabular}{lccccc}
\hline Bölüm & Kareler Toplamı & $\mathrm{df}$ & Kareler Ortalaması & $\mathrm{f}$ & $\mathrm{p}$ \\
\hline Gruplar arası & 1611,019 & 7 & 230,146 & 2,111 & \\
Gruplar içi & 124607,869 & 1143 & 109,018 & \\
Toplam & 126218,888 & 1150 & & & \\
\hline
\end{tabular}

$\mathrm{p}<.05$

\section{Öğretmen Adaylarının Dijital Vatandaşlık Ortalamalarının Sınıf Düzeylerine Göre İncelenmesi}

Öğretmen adaylarının dijital vatandaşlık puanlarının sınıf değişkenine göre farklılaşıp farklılaşmadığını belirlemek amacıyla tek faktörlü varyans analizi (OneWay ANOVA) yapılmıştır. Bulgular en yüksek dijital vatandaşlık puan ortalamasına 2. sınıfta öğrenim gören öğretmen adaylarının $(=94,8174)$ ve en düşük ortalamaya ise 4 . sınıfta öğrenim görmekte olan öğretmen adaylarının $(=94,5187)$ sahip olduğunu göstermektedir. Tablo 4'te görüldüğü üzere yapılan tek faktörlü varyans analizi sonucunda öğretmen adaylarının eğitim gördükleri sınıf düzeyleri ile dijital vatandaşlık puanları arasında anlamlı bir farka rastlanmamıştır ( $p=, 983)$.

Tablo 4. Öğretmen adaylarının dijital vatandaşlığa ilişkin ortalamalarının sınıf düzeyi değişkenine göre karşılaştırııması

\begin{tabular}{lccccc}
\hline Sınıf düzeyi & Kareler Toplamı & $\mathrm{df}$ & Kareler Ortalaması & $\mathrm{f}$ & $\mathrm{p}$ \\
\hline Gruplar arası & 18,091 & 3 & 6,030 &, 055 & \\
Gruplar içi & 126200,797 & 1147 & 110,027 & & \\
Toplam & 126218,888 & 1150 & & & \\
\hline
\end{tabular}

$\mathrm{p}<.05$ 
Öğretmen adaylarının dijital vatandaşlık puanlarının yaş değişkenine göre anlamlı bir farklılık gösterip göstermediğini belirlemek amacıyla tek faktörlü varyans analizi (OneWay ANOVA) yapılmıştır. Öğretmen adaylarının dijital vatandaşlık puan ortalamalarının yaş gruplarına göre değerlendirilmesinde ortalamaların oldukça yakın olduğu, en yüksek ortalamanın 19-20 yaş aralığındaki grupta, en düşük ortalamanın ise 21-22 yaş aralığındaki grupta olduğu sonucuna ulaşılmıştır. Yapılan analiz sonucunda öğretmen adaylarının yaş değişkenine göre dijital vatandaşlık puanlarının anlamlı şekilde farklılaşmadığı sonucuna ulaşılmıştır $(p=, 794)$. Tek faktörlü varyans analizi sonucunda elde edilen sonuçlar Tablo 5 'te verilmiştir.

Tablo 5. Öğretmen adaylarının dijital vatandaşlığa ilişkin ortalamalarının yaş değişkenine göre karşılaştırılması

\begin{tabular}{lccccc}
\hline Yaş & Kareler Toplamı & df & Kareler Ortalaması & $f$ & f \\
\hline Gruplar arası & 113,132 & 3 & 37,711 &, 794 \\
Gruplar içi & 126105,756 & 1147 & 109,944 & & \\
Toplam & 126218,888 & 1150 & & & \\
\hline
\end{tabular}

$p<.05$

\section{Öğretmen Adaylarının Dijital Vatandaşlık Puan Ortalamalarının Gelir Düzeylerine Göre İncelenmesi}

Öğretmen adaylarının dijital vatandaşlık puanlarının gelir durumlarına göre anlamlı şekilde farklılaşıp farklılaşmadı̆ını belirlemek amacıyla tek faktörlü varyans analizi (OneWay ANOVA) yürütülmüştür. Analiz sonucunda dijital vatandaşlık puan ortalamaları açısından en yüksek ortalamaya 500-750 TL arasında gelire sahip öğretmen adaylarının $(=95,7080)$, en düşük ortalamaya ise 751-1000 TL arasında gelir sahibi olan öğretmen adaylarının $(=92,9947)$ sahip olduğu belirlenmiştir. Tablo 6'da görüldüğü üzere yapılan tek faktörlü varyans analizi sonucunda öğretmen adaylarının aylık gelir durumları ile dijital vatandaşlık puanları arasında anlamlı bir fark bulunamamıştır $(p=0,86)$.

Tablo 6. Öğretmen adaylarının dijital vatandaşlığa ilişkin ortalamalarının gelir düzeyi değişkenine göre karşılaştırılması

\begin{tabular}{lccccc}
\hline Gelir düzeyi & Kareler Toplamı & df & Kareler Ortalaması & $f$ & p \\
\hline Gruplar arası & 727,861 & 3 & 242,620 & 2,205 & \\
Gruplar içi & 123563,565 & 1123 & 110,030 & & \\
Toplam & 124291,426 & 1126 & & & \\
\hline
\end{tabular}

$\mathrm{p}<.05$

\section{Öğretmen Adaylarının Dijital Vatandaşlık Ortalamalarının Bilgisayar Sahibi Olmalarına Göre İncelenmesi}

Öğretmen adaylarının dijital vatandaşlık düzeylerinin bilgisayar sahibi olma durumları açısından anlamlı şekilde farklılaşıp farklılaşmadığını belirlemek amacıyla bağımsız gruplar t-testi uygulanmıştır. Analiz sonuçlarına göre kendisine ait bir bilgisayarı olan öğretmen adayları ile bilgisayar sahibi olmayan öğretmen adayları arasında anlamlı bir fark bulunduğu görülmektedir $(t(834,035)=5,004, p<, 01)$. Yapılan analizler ile ilgili sonuçlar Tablo 7'de verilmiştir.

Tablo 7. Öğretmen adaylarının dijital vatandaşlığa ilişkin ortalamalarının bilgisayar sahibi olma değişkenine göre karşılaştırılması

\begin{tabular}{lcccccc}
\hline $\begin{array}{l}\text { Bilgisayar sahibi } \\
\text { olma }\end{array}$ & $\mathrm{N}$ & $\mathrm{X}$ & $\mathrm{SS}$ & $\mathrm{t}$ & $\mathrm{df}$ & $\mathrm{p}$ \\
\hline Evet & 712 & 95,9548 & 9,7984 & 5,004 & 834,035 & \\
Hayır & 436 & 92,7244 & 11,08551 & & \\
\hline $\mathrm{p}<.05$ & & & & &
\end{tabular}

\section{Öğretmen Adaylarının Dijital Vatandaşlık Ortalamalarının Bilgisayar Kullanım Sürelerine Göre İncelenmesi}

Öğretmen adaylarının dijital vatandaşlık puanlarının bilgisayar kullanma süreleri açısından anlamlı şekilde farklılaşıp farklılaşmadığını belirlemek amacıyla tek faktörlü varyans analizi (OneWay ANOVA) yürütülmüştür. Yapılan analiz sonucunda öğretmen adaylarının, dijital vatandaşıı puanlarının bilgisayar kullanma süresi değişkenine göre anlamlı şekilde farklılaştığı belirlenmiştir $(p=, 001)$. Post-hoc testleri sonucunda öğretmen adayları arasında 1-3 yıl arası bilgisayar kullanan grubun diğer üç grup ile anlamlı biçimde farklılaştığı sonucuna ulaşılmıştır.Tek faktörlü varyans analizi sonucunda elde edilen sonuçlar Tablo 8'de verilmiştir.

Tablo 8. Öğretmen adaylarının dijital vatandaşlığa ilişkin ortalamalarının bilgisayar kullanma süresi değişkenine göre karşılaştırılması 


\begin{tabular}{lccccc}
\hline $\begin{array}{l}\text { Bilgisayar kullanma } \\
\text { süresi }\end{array}$ & Kareler Toplamı & $\mathrm{df}$ & Kareler Ortalaması & $\mathrm{f}$ & $\mathrm{p}$ \\
\hline Gruplar arası & 1787,589 & 3 & 595,863 & 5,474 & \\
Gruplar içi & 123004,553 & 1130 & 108,854 & & \\
Toplam & 124792,143 & 1133 & & \\
\hline
\end{tabular}

$\mathrm{p}<.05$

\section{Öğretmen Adaylarının İnternete Bağlandıkları Araçlar}

Araştırma kapsamında öğretmen adaylarının internete bağlanmak için tercih ettikleri araçlar ile ilgili verdikleri yanıtlar incelenmiştir. Tablo 9'da görüldüğü üzere öğretmen adaylarının internete en çok bağlandıkları aracın dizüstü bilgisayar ( $N=516$ ) olduğu belirlenmiştir. Demografik analizler doğrultusunda yeni kuşak öğretmen adaylarının teknolojiye erişim anlamında sorun yaşamadığı, özellikle taşınabilir cihazların kullanılmasının öğretmen adayları arasında yaygın olduğu sonucuna ulaşılabilir. Demografik analiz sonuçları Tablo 9'da verilmiştir.

Tablo 9. Öğretmen adaylarının internete bağlandıkları araçlar

\begin{tabular}{lcc}
\hline Internete bağlanılan araçlar & $\mathrm{N}$ & $\%$ \\
\hline Dizüstü bilgisayar & 516 & 44,9 \\
Akıllı telefon & 488 & 42,5 \\
Masaüstü bilgisayar & 136 & 11,8 \\
Tablet & 5 & 0,4 \\
Diğer & 4 & 0,3 \\
Toplam & 1149 & 100 \\
\hline
\end{tabular}

\section{Öğretmen Adaylarının İnternete Bağlandıkları Yerler}

Öğretmen adaylarından kişisel bilgi formunda internete bağlanmak için sıklıkla tercih ettikleri yerleri belirtmeleri istenmiştir. Analizler ile ilgili sonuçlar Tablo 10'da verilmiştir.

Tablo 10. Öğretmen adaylarının internete bağlandıkları yerler

\begin{tabular}{lccc}
\hline Yer & $\mathrm{N}$ & $\%$ & 71,4 \\
\hline Ev & 819 & 2,5 & 1,2 \\
Okul & 29 & 24,9 & 100 \\
Internet Kafe & 14 & 285 & 147 \\
Diğer & 1147 & & \\
Toplam & & 100 \\
\hline
\end{tabular}

\section{Öğretmen Adaylarının Dijital Vatandaşlık Ortalamalarının Gün İçinde İnternet Kullanma Sürelerine Göre İncelenmesi}

Öğretmen adaylarının dijital vatandaşlık puanlarının gün içinde internet kullanma sürelerine göre anlamlı şekilde farklılaşıp farklılaşmadığını belirlemek amacıyla tek faktörlü varyans analizi (OneWay ANOVA) yürütülmüştür. Tek faktörlü varyans analizi sonucunda öğretmen adaylarının dijital vatandaşlık puan ortalamalarının gün içinde internet kullanma sürelerine göre anlamlı şekilde farklılaşmadığı sonucuna ulaşılmıştır $(p=, 445)$. Tek faktörlü varyans analizi sonuçları Tablo 11 'de verilmiştir.

Tablo 11. Öğretmen adaylarının dijital vatandaşlığa ilişkin ortalamalarının gün içinde internet kullanma süresi değişkenine göre karşılaştırılması

\begin{tabular}{lcccc}
\hline $\begin{array}{l}\text { Gün içinde internet } \\
\text { kullanma süresi }\end{array}$ & Kareler Toplamı & df & Kareler Ortalaması & $f$ \\
\hline Gruplar arası & 293,737 & 3 & 97,912 &, 891 \\
Gruplar içi & 125658,184 & & 1144 & 109,841 \\
Toplam & 125951,922 & & 1147 & \\
\hline
\end{tabular}

$\mathrm{p}<.05$

\section{Öğretmen Adaylarının Dijital Vatandaşlık Ortalamalarının Etkin E-Posta Kullanımlarına Göre İncelenmesi}

Öğretmen adaylarının dijital vatandaşıı ortalamalarını etkin e-posta kullanma durumları açısından anlamlı olarak farklılaşıp farklılaşmadığını belirlemek amacıyla bağımsız gruplar t-testi uygulanmıştır. Analiz sonucunda öğretmen adaylarının dijital vatandaşlık ortalamalarının etkin e-posta kullanımları açısından anlamlı olarak farklılaştığı sonucuna ulaşılmıştır $(\mathrm{t}(1148)=6,510, p<$ ,01). Kişisel bilgi formuna verdikleri yanıtlar incelendiğinde öğretmen adaylarının \%92,17'sinin ( $N=1060)$ etkin olarak bir e-posta 
hesabı kullandığı, \% 7,8'inin (N=90) ise etkin kullandıkları bir e-posta hesabı olmadığı belirlenmiştir. T-testi analizi sonuçları Tablo 12 'de verilmiştir.

Tablo 12. Öğretmen adaylarının dijital vatandaşlığa ilişkin ortalamalarının etkin e-posta kullanma durumu değişkenine göre karşılaştırılması

\begin{tabular}{lcccccc}
\hline Etkin e-posta adresi & $\mathrm{N}$ & $\mathrm{X}$ & $\mathrm{SS}$ & $\mathrm{t}$ & $\mathrm{df}$ & $\mathrm{p}$ \\
\hline Evet & 1060 & 95,2588 & 10,25118 & 6,510 & 1148 &, 000 \\
Hayır & 90 & 87,9017 & 10,77636 & & & \\
\hline
\end{tabular}

p<.05

\section{Öğretmen Adaylarının Dijital Vatandaşlık Ortalamalarının E-Devlet Şifresine Sahip Olma Durumlarına Göre İncelenmesi}

Öğretmen adaylarının dijital vatandaşlık puan ortalamalarının e-devlet şifresine sahip olma durumlarına göre anlamlı olarak farklılaşıp farklılaşmadığını tespit etmek amacıyla bağımsız gruplar t-testi uygulanmıştır. Tablo 13 'te görüldüğü üzere t-testi analizi sonucunda elde edilen bu bulgulara dayanarak öğretmen adaylarının dijital vatandaşlık puan ortalamalarının e-devlet şifresine sahip olma durumlarına göre anlamlı şekilde farklılaştığı sonucuna ulaşılabilir $(t(45,452)=4,444, p<, 01)$. T-testi analizi sonuçları Tablo 13 'te verilmiştir.

Tablo 13. Öğretmen adaylarının dijital vatandaşığa ilişkin ortalamalarının e-devlet şifresine sahip olma değişkenine göre karşılaştırılması

\begin{tabular}{lccccc}
\hline E-devlet şifresi & $N$ & $x$ & SS & df & p \\
\hline Evet & 1104 & 95,0429 & 10,26590 & 4,444 \\
Hayır & 44 & 86,7426 & 12,21883 & & \\
\hline
\end{tabular}

$\mathrm{p}<.01$

\section{Öğretmen Adaylarının Kullandığı E-Devlet Uygulamaları}

Öğretmen adaylarından kişisel bilgi formunda e-devlet şifresi ile kullandıkları uygulamaları belirtmeleri istenmiştir. Verilen benzer cevaplar bir başlık altında toplanmaya çalışılmıştır. Örneğin; "kyk”, "kyk genciz biz”, "genciz biz” cevapları "Kyk-Genciz Biz” başlı̆̆ı altında, "nüfus", "nüfus için”, "nüfus belgesi alma”, "nüfus kaydı" cevapları "Nüfus İşlemleri” başlığı altında toplanmıştır. En çok kullanılan uygulamalar incelendiğinde eğitim ile ilgili uygulamaların sıralamada üst sıralarda yer aldığı, bunu "soy ağacı" uygulamasının izlediği ve daha sonra ise sağlık ile ilgili uygulamaların tercih edildiği görülmektedir. Öğretmen adaylarının verdikleri bilgilerin demografik analizi sonucunda elde edilen sonuçlar Tablo 14'te verilmiştir.

Tablo 14. Öğretmen adaylarının e-devlet şifresi ile kullandığı uygulamalar

\begin{tabular}{lcc}
\hline E-Devlet uygulamaları & $N$ & $\%$ \\
\hline KYK-Genciz Biz & 169 & 31,1 \\
ÖSYM & 56 & 10,3 \\
Öğrenci belgesi alma & 54 & 9,9 \\
Soy ağacı & 38 & 7,0 \\
MHRS & 32 & 5.9 \\
E-Nabız & 29 & 5,3 \\
Eğitim bilgileri & 20 & 3.7 \\
Nüfus işlemleri & 16 & 2,9 \\
SGK & 16 & 2,9 \\
Üniversite e-kayıt & 16 & 2,9 \\
Burs işlemleri & 15 & 2,8 \\
Adli Sicil Sorgulama & 11 & 2,0 \\
YöK & 10 & 1,8 \\
İkametgâh & 9 & 1,7 \\
Öğrenci bilgi sistemi & 8 & 1,5 \\
Banka işlemleri & 7 & 1,3 \\
Diğer & 37 & 7,0 \\
Toplam & 543 & 100 \\
\hline
\end{tabular}




\section{Öğretmen Adaylarının En Sık Kullandığı Sosyal Ağlar}

Kişisel bilgi formunda öğretmen adaylarından üye oldukları sosyal ağları belirtmeleri istenmiştir. Öğretmen adaylarının \%98,4'ünün sosyal ağlara üye olduğu belirlenmiştir. Bunun yanısıra en sık kullandıkları sosyal ağı belirtmeleri de istenmiştir. Öğretmen adaylarının \%1,6'sını oluşturan 18 kişilik bir grup hiçbir sosyal ağı kullanmadığını belirtmiştir. Bulgular öğretmen adayları arasında en sık kullanılan sosyal ağın "Instagram” olduğunu ve sosyal ağların yaygın şekilde kullanıldığını göstermektedir. Öğretmen adaylarının verdikleri cevapların analizi sonucunda elde edilen sonuçlar Tablo 15 'te verilmiştir.

Tablo 15. Öğretmen adaylarının en sık kullandığı sosyal ağlar

\begin{tabular}{|c|c|c|}
\hline Sosyal Ağ & $\mathrm{N}$ & $\%$ \\
\hline Instagram & 853 & 75,0 \\
\hline Twitter & 98 & 8,6 \\
\hline Whatsapp & 82 & 7,2 \\
\hline Facebook & 40 & 3,5 \\
\hline Youtube & 10 & 0,9 \\
\hline E-Nabız & 2 & 0,2 \\
\hline Snapchat & 35 & 3 \\
\hline Diğer & 18 & 1,6 \\
\hline Toplam & 1138 & 100 \\
\hline
\end{tabular}

\section{Öğretmen Adaylarının Dijital Vatandaşlık Ortalamalarının En Sık Kullandıkları Sosyal Ağda Geçirdikleri Süreye Göre incelenmesi}

Öğretmen adaylarının dijital vatandaşlık puanlarının en sık kullandıkları sosyal ağda geçirdikleri süreye göre incelenmesi amacıyla tek faktörlü varyans analizi (OneWay ANOVA) uygulanmıştır. Tek faktörlü varyans analizi sonucunda öğretmen adaylarının dijital vatandaşık puanlarının en sık kullandıkları sosyal ağda geçirdikleri süreye göre anlamlı şekilde farkılaştığı belirlenmiştir $(p=, 011)$. Tukey HSD testi sonucunda; anlamlı farkın gün içinde en sık kullanılan sosyal ağda 4-6 saat arası vakit geçiren grup ile gün içinde 6 saatten fazla vakit geçiren grup arasında ve 6 saatten fazla vakit geçiren grubun lehine olduğu sonucuna ulaşılmıştır. Tek faktörlü varyans analizi sonucunda elde edilen sonuçlar Tablo 16 ' da verilmiştir.

Tablo 16. Öğretmen adaylarının dijital vatandaşlığa ilişkin ortalamalarının en sık kullandıkları sosyal ağda geçirdikleri süre değişkenine göre karşılaştırılması

\begin{tabular}{|c|c|c|c|c|c|}
\hline $\begin{array}{l}\text { Sosyal ağda geçirilen } \\
\text { süre }\end{array}$ & Kareler Toplamı & df & Kareler Ortalaması & $f$ & $\mathrm{p}$ \\
\hline Gruplar arası & 1215,194 & 3 & 405,065 & 3,731 & 011 \\
\hline Gruplar içi & 123885,157 & 1141 & 108,576 & & \\
\hline Toplam & 125100,351 & 1144 & & & \\
\hline
\end{tabular}

$\mathrm{p}<.05$

\section{TARTIŞMA VE SONUÇ}

Bu araştırma kapsamında öğretmen adaylarının dijital vatandaşlık düzeylerinin betimlenmesi ve bu düzeylerin farklı değişkenler açısından incelenmesi amaçlanmıştır. Araştırmanın bulguları öğretmen adaylarının dijital vatandaşlık düzeylerinin demografik değişken olarak belirlenen cinsiyet ve öğrenim görülen bölüme göre anlamlı şekilde farklılaştığı ancak sınıf, yaş aralığı ve gelir düzeyine göre anlamlı şekilde farklılaşmadığını göstermiştir.

Bulgular öğretmen adaylarının dijital vatandaşlık düzeyleri ile cinsiyetleri arasında istatistiksel olarak anlamlı bir fark bulunduğunu ve bu anlamlı farkın kadın öğretmen adayları lehine olduğunu göstermektedir. Alanyazında cinsiyet değişkeninin dijital vatandaşlık düzeyi ile ilgili en sık araştırılan değişkenlerden biri olduğu görülmüştür. Öğretmen adaylarını inceleyen Kocadağ (2012) ile üniversite öğrencileri ile çalışan Som-Vural (2016) araştırmalarında dijital vatandaşlık düzeyinin cinsiyet değişkeni açısından anlamlı olarak farklılaştığı sonucuna ulaşmışlardır. Som-Vural (2016) üniversite öğrencilerinin dijital vatandaşlık düzeylerinin kadınlar lehine anlamlı şekilde farklılaştığı sonucuna ulaşırken, Kocadağ (2012) ve Özerbaş ve Kuralbayeva (2018) cinsiyet ile ilgili anlamlı farklılığın erkekler lehine olduğunu belirlemiştir. Alanyazın incelendiğinde erkekler lehine anlamlı fark olduğu sonuca ulaşan Kocadağ (2012), araştırmasında bunun sebebinin kadınların dijital ortamlardaki çekimser davranış biçiminden kaynaklanabileceğini belirtmiştir. Ancak Çakır ve Oktay (2013) araştırmalarında kadın öğretmenlerin teknolojiye karşı tutum ortalamalarının erkek öğretmenlere göre daha yüksek olduğu sonucuna ulaşmıştır. Bunun yanısıra Kabataş (2019) yaşam boyu öğrenmeye yönelik tutumları cinsiyet açısından incelediği çalışmasında kadın öğretmen adayları lehine bir fark bulmuştur. Som-Vural (2016) tarafından yapılan çalışmada da üniversite öğrencileri arasında kadınlar lehine bir farklılık olması sonucu Kocadağ’ın (2012) belirttiği kadınların dijital ortamlardaki çekimser davranışlarının son yıllarda değişmesi olarak yorumlanabilir. Bu bulgunun da kadın öğretmen adaylarının dijital vatandaşlık düzeylerinin erkek öğretmen adaylarına göre daha fazla artmasını 
destekleyecek bir bulgu olduğu söylenebilir. Bunun yanı sıra bu değişimin nedenlerinin incelenmesi gelecekteki çalışmalarda cinsiyet ile ilgili yapılacak çıkarımlar açısından önemli ve gereklidir.

Öğretmen adaylarının dijital vatandaşlık düzeyleri öğrenim görmekte oldukları bölüm açısından incelendiğinde dijital vatandaşlık düzeylerinin bölüm açısından anlamlı olarak farklılaştığını sonucuna ulaşılmıştır. Benzer şekilde Kocadağ (2012), öğretmen adaylarının dijital vatandaşıı düzeylerini öğrenim gördükleri bölüm açısından incelediği çalışmasında dijital vatandaşlık düzeylerinin öğrenim görülen bölüme göre anlamlı şekilde farklılaştığı sonucuna ulaşmıştır. Ayrıca Özerbaş ve Kuralbayeva (2018) çalışmalarında dijital vatandaşıı düzeylerinin bölüm değişkeni açısından anlamlı olarak farklılaştığı sonucuna ulaşmıştır. Araştırma kapsamında dijital vatandaşlık düzeyi en yüksek olan bölümün Bilgisayar ve Öğretim Teknolojileri Eğitimi (BÖTE), en düşük dijital vatandaşlık düzeyine sahip bölümün ise Sınıf Öğretmenliği bölümü olduğu belirlenmiştir. Bu bulgu BÖTE bölümü öğretmen adaylarının bölümleri gereği bilgisayar ile daha uzun süre etkileşim içinde olmaları ve bilgisayar kullanmaya yönelik yeterliliklerinin diğer bölümlerden daha ileri düzeyde olması ile bağlantılı olabileceği şeklinde yorumlanabilir. Dijital vatandaşlık ile ilgili BÖTE bölümü öğrencileri ile çalışan Kaya ve Kaya (2014) araştırmasında bu bölümdeki öğretmen adaylarının dijital vatandaşlık kavramını doğru algıladıkları ve alt boyutlar bağlamında bilinçli ve dikkatli oldukları sonucuna ulaşmıştır. Dijital vatandaşlık düzeyine yönelik yapılmış çalışmaların bulguları doğrultusunda, bilgisayar ile daha fazla etkileşim içinde olan bir bölümde öğrenim görüyor olmanın dijital vatandaşlık düzeyi ile bu kavrama yönelik bilinç ve doğru algılama açısından bir etkisinin olduğu çıkarımında bulunulabilir. Ancak çalışma adına önemli bir bulgu BÖTE bölümü dışındaki bölümlerin dijital vatandaşlık puan ortalamalarının da birbirine yakın olmasıdır. Bilgisayar odaklı eğitim verilen bir bölüm dışındaki bölümlerin de dijital vatandaşlık puanlarının yüksek ve birbirine yakın değerlerde olması internetin yaygın kullanımı ve artan kullanım alanlarının bir sonucu olarak görülebilir.

Araştırmada öğretmen adaylarının dijital vatandaşlık düzeylerinin sınıf düzeylerine göre anlamlı bir şekilde farklılaşmadığı sonucuna ulaşılmıştır. Alanyazında bu bulguyu destekleyen çalışmalar olduğu görülmektedir (Sakallı, 2015; Aslan, 2016; Özerbaş ve Kuralbayeva, 2018). Fakat Som-Vural (2016), üniversite öğrencilerinin dijital vatandaşlık düzeyleri ile sınıf düzeyleri arasında istatistiksel olarak anlamlı bir fark olduğu sonucuna ulaşmıştır ancak bu farkın pratikte anlamlı olmayabileceğini belirtmiştir. Bulgular ışı̆̆ında bilgisayar, internet ve mobil cihazların yaygınlaşarak her yaştan kullanıcı tarafından sıkça kullanılmasının dijital vatandaşlık toplam puanları anlamında sınıf düzeylerini birbirine yaklaştırmış olabileceği çıkarımında bulunulabilir. Benzer şekilde araştırmada, dijital vatandaşlık düzeyinin yaş değişkeni açısından anlamlı olarak farklılaşmadığı sonucuna ulaşılmıştır. Bu bulguya paralel olarak Aslan (2016) araştırmasında dijital vatandaşlık düzeylerinin yaş değişkenine göre anlamlı bir farklılık göstermediği sonucuna ulaşmıştır. Fakat alanyazında dijital vatandaşlığı yaş değişkeni açısından inceleyen farklı araştırmalarda anlamlı fark bulunduğu da görülmüştür (Kocadağ, 2012; Tatlı, 2018). Farklı yaş gruplarının birbirlerine yakın dijital vatandaşlık düzeylerine sahip olmasının, çalışmada daha önce de belirtildiği gibi dijital teknolojilerin yaygınlaşmasından kaynaklanmış olabileceği düşünülmektedir.

Araştırmada öğretmen adaylarının dijital vatandaşlık düzeylerinin aylık gelir durumlarına göre anlamlı şekilde farklılaşmadığı sonucuna ulaşıımıştır. Ancak Som-Vural’ın (2016), üniversite öğrencilerinin dijital vatandaşlık düzeylerinin aylık gelir değişkenine göre anlamlı şekilde farklılaştığı sonucuna ulaştığı görülmüştür. Benzer şekilde Kocadağ (2012) ve Aslan (2016) araştırmalarında katılımcıların ailelerinin ortalama gelir düzeyinin dijital vatandaşlık düzeyi açısından anlamlı bir farklılık oluşturduğu sonucuna ulaşmışlardır. Alanyazındaki bu değişken ile ilgili farklı bulguların, örneklem ve araştırmanın yapıldığı yıl gibi farklılıklardan kaynaklanabileceği göz önünde bulundurulduğunda; farklı gelir düzeylerine sahip grupların, dijital vatandaşıı düzeyleri açısından anlamlı farklılaşmamasının bu gelir gruplarının teknolojiye erişim konusunda birbirlerine yakın imkanlara sahip olabilme ihtimalinden kaynaklanabileceği söylenebilir.

Öğretmen adaylarının dijital vatandaşlık düzeyleri teknolojiye erişim olanakları açısından incelendiğinde, dijital vatandaşlık düzeylerinin bilgisayar sahibi olma, bilgisayar kullanma süresi (yıl bazında), gün içinde internet kullanma süresi, en sık kullanılan sosyal ağda geçirilen süre, e-devlet şifresi sahibi olma ve etkin bir e-posta adresi kullanma açısından anlamlı şekilde farklılaştığı sonucuna ulaşılmıştır. Araştırmanın bulguları, öğretmen adaylarının büyük bir çoğunluğunun bilgisayar sahibi olduğu ve 7 yıldan 10 yıla kadar bilgisayar kullanma deneyimlerinin bulunduğunu göstermektedir. Alanyazında dijital vatandaşlık düzeyini bilgisayar sahibi olma açısından inceleyen çalışmalar arasında bu çalışmanın bulguları ile örtüşen çalışmalar bulunmaktadır (Aslan, 2016; Kocadağ, 2012). Ancak Kabataş (2019) araştırmasında bu bulgulardan farklı bir sonuca ulaşarak 1. sınıfta öğrenim gören öğretmen adaylarının dijital vatandaşıı düzeylerinin bilgisayar sahibi olma değişkenine göre anlamlı şekilde farklılaşmadığı sonucuna ulaşmıştır.

Öğretmen adaylarının bilgisayar deneyimlerine yönelik yapılan analizler sonucunda, dijital vatandaşlık puan ortalamalarının yıl bazında bilgisayar kullanma sürelerine göre anlamlı olarak farklılaştığı sonucuna ulaşılmıştır. Alanyazında öğretmen adaylarının dijital vatandaşlık düzeylerini yıl bazında bilgisayar kullanma süreleri açısından inceleyen bir araştırma bulunmamakla birlikte öğretmen adaylarının dijital vatandaşıık düzeylerini yıl bazında internet kullanma süreleri bakımından inceleyen araştırmalar bulunmaktadır. Al-Zahrani (2015), araştırmasında dijital vatandaşlığı etkileyen faktörler arasında bilgisayar deneyimi, gün içinde ortalama teknoloji kullanımı, internete yönelik tutum ve bilgisayar öz-yeterliliği olduğu sonucuna ulaşmıştır. Bu araştırmaların bulguları mevcut araştırmanın bulguları ile örtüşmektedir. Ayrıca, Sakallı (2015) araştırmasında dijital vatandaşlık düzeyinin algılanan internet kullanma becerisine göre anlamlı şekilde farklılaştığı sonucuna ulaşmıştır. Benzer şekilde Tatlı (2018) öğretmenlerin; dijital vatandaşlık düzeyleri ile internet ve bilgisayar kullanma becerileri arasında pozitif yönlü, orta düzeyde ve anlamlı bir ilişki olduğunu belirlemiş̧tir. Öğretmenlerin internet ve bilgisayar kullanma düzeyleri arttıkça dijital vatandaşlık düzeylerinin de arttığını vurgulamıştır. Özerbaş ve Kuralbayeva'ya (2018) göre teknoloji altyapısı dijital vatandaşlık düzeyinin

| Kastamonu Eğitim Dergisi, 2020, Vol. 28, No. 61 
yükselmesinde etkilidir. Bu bilgiler doğrultusunda teknolojiye erişim ile dijital vatandaşlık düzeyi arasında pozitif bir ilişki olduğu söylenebilir.

Araştırmanın dikkat çeken bir diğer bulgusu alanyazında dijital vatandaşlık ile bağlantılı olarak görülen gün içinde internet kullanma süresinin (Al-Zahrani, 2015; Aslan, 2016; Choi, Cristol ve Gimbert, 2018; Sakallı, 2015; Som-Vural, 2016; Kabataş 2019) bu araştırmada anlamlı şekilde farklılaşmamasıdır. Bulgulardaki dijital vatandaşlık düzeyinin gün içinde internette geçirilen süre değişkeni açısından farklılaşmasının nedenlerinin ortaya konulması amacıyla nitel araştırmalar tasarlanarak gün içinde internette geçirilen zaman değişkeninin dijital vatandaşlık düzeyine etkisinin derinlemesine incelenmesi faydalı olacaktır.

Öğretmen adaylarının dijital vatandaşlık düzeyleri etkin bir e-posta kullanma değişkeni açısından anlamlı şekilde farklılaşmaktadır. Alanyazında bu bulguya paralel çalışmalar bulunmaktadır (Çepni, Oğuz ve Kılcan, 2014; Kocadağ, 2012). Araştırmanın bir diğer bulgusu öğretmen adaylarının dijital vatandaşlık düzeylerinin e-devlet şifresine sahip olmaları açısından anlamlı şekilde farklılaştığını göstermektedir. Analiz sonucunda öğretmen adaylarının çoğunluğunun $(\% 96,16)$ e-devlet şifresine sahip olduğu, küçük bir grubun $(\% 3,84)$ ise e-devlet şifresinin bulunmadığı sonucuna ulaşılmıştır. Bunun yanısıra öğretmen adaylarının dijital vatandaşlık düzeyleri ile en sık kullandıkları sosyal ağda geçirdikleri süre arasında anlamlı bir farklılık olduğu belirlenmiştir. Bu anlamlı farkın gün içinde en sık kullanılan sosyal ağda 4-6 saat arası vakit geçiren grup ile gün içinde 6 saatten fazla vakit geçiren grup arasında ve 6 saatten fazla vakit geçiren grubun lehine olduğu görülmüştür.

Sonuç olarak çalışmaya katılan öğretmen adaylarının dijital vatandaşlık düzeylerinin yüksek düzeyde olduğu ve kadın öğretmen adaylarının dijital vatandaşlık düzeyinin erkek öğretmen adaylarından daha yüksek olduğu belirlenmiştir. Bölüm bazında değerlendirildiğinde en yüksek dijital vatandaşlık puanına BÖTE bölümündeki öğretmen adaylarının, en düşük puana ise Sınıf Öğretmenliği bölümündeki öğretmen adaylarının sahip olduğu belirlenmiştir. Ancak tüm bölümlerin dijital vatandaşlık puanlarının birbirine yakın olması yeni kuşak öğretmen adaylarının dijital vatandaşlık açısından daha bilinçli bir grup olduğu şeklinde yorumlanabilir. Öğretmen adaylarının büyük bir çoğunluğunun etkin bir e-posta adresine sahip olduğu, sosyal ağları ve e-devlet uygulamalarını etkin olarak kullandıkları sonucuna ulaşılmıştır. Dijital vatandaşlık düzeyinin gelir düzeyi, sınıf ve yaşa göre farklılaşmadığı ancak internet kullanma davranışları açısından farklılaştığı sonucuna ulaşılmıştır.

\section{ÖNERILER}

Öğretmen eğitiminde dijital vatandaşlık bilincinin oluşması için öğretim programlarında gerekli bilgilerin verilmesinin yanı sıra uygulama ile ilgili olanakların sağlanmasının gerekli olduğu görülmektedir. Çalışma kapsamında elde edilen bulgular ışığında dijital vatandaşlık bilincinin yaygınlaşmasına katkıda bulunmak için ve gelecekte yapılacak araştırmalara yönelik önerilerde bulunulmaya çalışılmıştır:

- Öğrencilere dijital vatandaşlık bilinci verilmesinde öğretmenlerin önemli bir yeri olduğu için bu araştırmada öğretmen adayları ile çalışımıştır. Ancak öğretmen adaylarını yetiştiren öğretim elemanları ve akademisyenlerin dijital vatandaşlık düzeylerinin ortaya konulması ile ilgili betimleyici çalışmalar yapılması da alanyazına katkıda bulunabilir.

- Bu çalışma örneklemi açısından belirlenen devlet üniversitesinde öğrenim görmekte olan öğretmen adayları ile sınırlıdır. Araştırmanın Türkiye örneklemini temsil edebilecek bir grup ile tekrarlanması öğretmen adaylarının dijital vatandaşlık düzeylerinin üniversite ve bölgelere dağılımı açısından da ortaya konulmasına olanak tanıyabilir. Bunun yanı sıra bu çalışma kapsamında araştırılmayan farklı değişkenlerin (dil ile ilgili yeterlilik, dijital vatandaşlık ile ilgili ders almak, vb.) incelenmesi alanyazına katkı sağlayacaktır.

- Bu tarama çalışmasından elde edilen verilerin nitel tasarımlar ile desteklenmesi gereksinimlerin belirlenmesi anlamında önemlidir. Karma ve nitel araştırmaların yapılması dijital vatandaşık ile ilgili verilecek eğitimlerin ve oluşturulacak içeriklerin belirlenmesine yardımcı olacaktır.

- Çalışma kapsamında bütün bölümlerden ve farklı sınıf düzeylerinden öğrencilere ulaşılmaya çalışılmıştır. Ancak bu çalışma Eğitim fakültesine yeni başlayan öğretmen adayları ile tekrarlanarak öğretmen adaylarının dijital vatandaşlık düzeylerinin belirlenmesi ve buna yönelik derslere yönlendirilmeleri önerilmektedir. Bu öğrencilerin dijital vatandaşlık düzeylerinin belirlenmesinin ardından yönlendirilmesi ile farklı düzeydeki öğrencilerin ihtiyaçlarına yönelik ders içerikleri ve uygulamalar geliştirilmesi adına yararlı olacaktır. Ayrıca bu şekilde tasarlanan öğretim süreçlerine dâhil olan öğrencilerin öğrenim süreçlerinde dijital vatandaşlık açısından değişimlerine yönelik bilgi sahibi olunması da mümkün olacaktır.

- Gelecekte yapılacak araştırmalarda öğretmen adaylarının akademik başarıları ile dijital vatandaşlık düzeyleri arasındaki ilişki incelenebilir.

- Öğretmen adaylarının dijital vatandaşlık yeterliliklerinin ve bilgi düzeylerinin geliştirilmesi için yeni düzenlenen öğretim programında bütün bölümlerin öğretim programları içerisine alınan Öğretim Teknolojileri dersi kapsamında dijital vatandaşlık ile ilgili içeriklerin eklenmesi önerilmektedir.

- Dijital vatandaşlık bilincinin yaygınlaşması toplumdaki her bireyin dijital vatandaşlığı oluşturan alt boyutlar ile ilgili bilinçli ve eğitimli olabilmesi ile mümkündür. Bu bağlamda ebeveyn ve okul yöneticileri ile çalışmalar yapılması da kritik önem taşımaktadır. 


\section{KAYNAKÇA}

Akçayır, M., Dündar, H. \& Akçayır, G. (2016). What makes you a digital native? Is it enough to be born after 1980? Computers in Human Behavior, 60, 435-440.

Al-Zahrani, A. (2015). Toward Digital Citizenship: Examining Factors Affecting Participation and Involvement in the Internet Society among Higher Education Students. International Education Studies, 8 (12), 203-217.

Aslan, S. (2016). Ilköğretim sosyal bilgiler öğretmen adaylarının dijital vatandaşılk davranışlarının bazı değişkenler açısından incelenmesi, (Yayımlanmamış yüksek lisans tezi). Fırat Üniversitesi, Elazığ.

Bakır, E. (2016). Sını öğretmeni adaylarının dijital vatandaşlık seviyelerinin dijital vatandaşlık alt boyutlarına göre incelenmesi, (Yayımlanmamış yüksek lisans tezi). Karadeniz Teknik Üniversitesi, Trabzon.

Bennett, S., Maton, K. \& Kervin, L. (2008). The 'digital natives' debate: A critical review of the evidence. British Journal of Educational Technology, 39 (5), 775-786.

Berardi, R. P. (2015). Digital citizenship: elementary educator perceptions and formation of instructional value and efficacy, (Yayımlanmamış doktora tezi). Immaculata University, Philadelphia.

Büyüköztürk, Ş., Çakmak, E. K., Akgün, Ö. E., Karadeniz, Ş. \& Demirel, F. (2017). Bilimsel araştırma yöntemleri. Ankara: Pegem Akademi.

Choi, M., Cristol, D. \& Gimbert, B. (2018). Teachers as digital citizens: The influence of individual backgrounds, internet use and psychological characteristics on teachers' levels of digital citizenship. Computers \& Education, 121, 143-161.

Choi, M., Glassman, M. \& Cristol, D. (2017). What it means to be a citizen in the internet age: Development of a reliable and valid digital citizenship scale. Computers \& Education, 107, 100-112.

Çakır, R. \& Oktay, S. (2013). Bilgi Toplumu Olma Yolunda Öğretmenlerin Teknoloji Kullanımları. Gazi Üniversitesi Endüstriyel Sanatlar Eğitim Fakültesi Dergisi, (30), 35-54.

Çepni, O., Oğuz, S. \& Kılcan, B. (2014). İlköğretim öğrencilerinin dijital vatandaşlığa yönelik görüşleri. Türkiye Sosyal Araştırmalar Dergisi, 18(3), 251-266.

Elçi, A. C. \& Sarı, M. (2016). Bilişim teknolojileri ve yazılım dersi öğretim programına yönelik öğrenci görüşlerinin dijital vatandaşlık bağlamında incelenmesi. Çukurova Üniversitesi Sosyal Bilimler Enstitüsü Dergisi, 25 (3), 87-10.

Fırat, M. (2016). 21. Yüzyılda uzaktan öğretimde paradigma değişimi. Yüksekögretim ve Bilim Dergisi, 6( 2), 142-150.

Fraenkel, J.R., Wallen, N.E. \& Hyun, H.H. (2012). How to Design and Evaluate Research in Education: Preparing Research Proposals and Reports. 8th Ed. McGraw-Hill.

Gleason, B. \& von Gillern, S. (2018). Digital citizenship with social media: Participatory practices of teaching and learning in secondary education. Educational Technology \& Society, 21 (1), 200-212.

Görmez, E. (2016). Öğretmen adaylarının" dijital vatandaşlık ve alt boyutları" hakkındaki görüşleri (bir durum çalışması). Electronic Turkish Studies, 11(21), 52-74.

Gülseçen, S., Özdemir, Ş., Çelik, S., Uğraş, T. \& Özcan, M. (2014). Dijital dünyadan yansımalar: Bilgide ve vatandaşlıkta değişim. XIX. Türkiye'de internet Konferansı, 27-29.

Hollandsworth, R., Dowdy, L. \& Donovan, J. (2011). Digital citizenship in K-12: It takes a village. TechTrends, 55(4), 37-47.

ISTE (2014). International Society for Technology in Education (ISTE) Standards for Students. 10.06 .2018 tarihinde https://www.iste.org/standards/for-students adresinden erişilmiştir.

Jones, L. M. \& Mitchell, K. J. (2016). Defining and measuring youth digital citizenship. New Media \& Society, 18(9), $2063-2079$.

Kabataş, S. (2019). Öğretmen adaylarının dijital vatandaşlık algılarının yaşam boyu öğrenme tutumları ve e-öğrenmeye hazır bulunuşluğu açısından değerlendirilmesi,(Yayımlanmamış yüksek lisans tezi). Bartın Üniversitesi, Bartın.

Kara, N. (2018). Understanding University Students' Thoughts and Practices about Digital Citizenship: A Mixed Methods Study. Educational Technology \& Society, 21 (1), 172-185.

Karaduman, H. (2011). 6. sınıf sosyal bilgiler dersinde dijital vatandaşlığa dayalı etkinliklerin öğrencilerin dijital ortamdaki tutumlarına etkisi ve öğrenme öğretme sürecine yansımaları, (Yayımlanmamış doktora tezi).Marmara Üniversitesi, İstanbul.

Karasar, N., (1984). Bilimsel Araştırma Metodu. Ankara: Hacettepe Taş Kitapçılık.

Kaya, A. \& Kaya, B. (2014). Öğretmen adaylarının dijital vatandaşıı algısı. International Journal of Human Sciences, 11 (2), $346-361$. doi: 10.14687/ijhs.v11i2.2917

Kline, R. B. (2005). Principles and Practice of Structural Equation Modeling. Third ed. Guilford Press: New York.

Kocadağ, T. (2012). Öğretmen adaylarının dijital vatandaşıık düzeylerinin belirlenmesi, (Yayımlanmamış yüksek lisans tezi). Karadeniz Teknik Üniversitesi, Trabzon.

Kuş, Z., Güneş, E., Başarmak, U., \& Yakar, H. (2017). Gençlere Yönelik Dijital Vatandaşılı Ölçeğinin Geliştirilmesi: Geçerlik ve Güvenirlik Çalışması. Journal of Computer and Education Research, 5(10), 298-316.

Netwong, T. (2016). The Using of the Moodle e-Learning Management System at Suan Dusit University to Develop Digital Citizenship and Learning Achievement in Information Technology. Asean Journal of Education, 2(2), 87-99.

Oblinger, D., Oblinger, J. L., \& Lippincott, J. K. (2005). Educating the net generation. Brockport Bookshelf.

Odabaşı, H. F., Mısırlı, Ö., Günüç, S., Timar, Z., Ersoy, M., Som, S., Dönmez, F. İ., Akçay, O. \& Erol, O. (2012). Eğitim için yeni bir ortam: Twitter. Anadolu Journal of Educational Sciences International (AJESI), 2(1), 89-103. 
Oyedemi, T. T. D. (2012). The partially digital: Internet, citizenship, social inequalities, and digital citizenship in South Africa, (Yayımlanmamıs doktora tezi). University of Massachusetts Amherst.

Özdamar, K (2004). Paket Programlar ile Istatistiksel Veri Analizi I. 5. Baskı, Kaan Kitabevi, Eskişehir.

Özerbaş, M. A. \& Kuralbayeva, A. (2018). Türkiye ve Kazakistan öğretmen adaylarının dijital okuryazarlık düzeylerinin değerlendirilmesi. Muğla Sıtkı Koçman Üniversitesi Eğitim Fakültesi Dergisi, 5(1), 16-25.

Öztürk, M. (2015). Ortaokul öğrencilerinin dijital vatandaşılık düzeyleri, (Yayımlanmamış yüksek lisans tezi). Kastamonu Üniversitesi, Kastamonu. Pescetta, M. (2011). Teaching digital citizenship in a global Academy, (Yayımlanmamış doktora tezi). Nova Southeastern University, Florida.

Prensky, M. (2001). Digital natives, digital immigrants. On the Horizon, 9(5), 1-6.

Ribble, M. (2011). Digital Citizenship in Schools (2nd ed.). Eugene, OR: International Society for Technology in Education.

Ribble, M. (2015). Digital Citizenship in Schools, Nine Elements All Students Should know. (3rd ed.) Washington DC: International Society for Technology in Education.

Sakallı, H. (2015). Sınıf öğretmeni adaylarının dijital vatandaşlık düzeyleri ile siber zorbalık eğilimleri arasındaki ilişkinin incelenmesi, (Yayımlanmamış yüksek lisans tezi). Adnan Menderes Üniversitesi, Aydın.

Som-Vural, S. (2016). Üniversite öğrencilerinin bakış açısıyla dijital vatandaşlık göstergelerinin incelenmesi, (Yayımlanmamış doktora tezi).Anadolu Üniversitesi, Eskişehir.

Şahin, M. C. (2009). Yeni Binyılın Öğrencileri'nin Özellikleri. Anadolu Üniversitesi Sosyal Bilimler Dergisi, 9(2), 155-172.

Tapscott, D. (1998). Growing up digital: The rise of the net generation. New York: McGraw-Hill.

Tatlı, A. (2018). Öğretmenlerin dijital vatandaşık düzeylerinin bilgi okuryazarlığı ile internet ve bilgisayar kullanım özyeterlikleri bağlamında değerlendirilmesi, (Yayımlanmamış yüksek lisans tezi). Necmettin Erbakan Üniversitesi, Konya. 